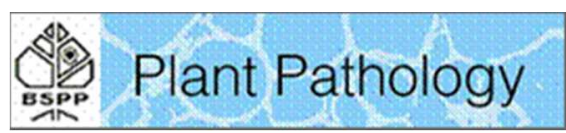

\title{
Rhizogenic agrobacteria in hydroponic crops: epidemics, diagnostics and control
}

\begin{tabular}{|r|l|}
\hline Journal: & Plant Pathology \\
\hline Manuscript ID & Draft \\
\hline Manuscript Type: & Review Article \\
\hline Complete List of Authors: & $\begin{array}{l}\text { Bosmans, Lien } \\
\text { Moerkens, Rob } \\
\text { Wittemans, Lieve } \\
\text { De Mot, Rene } \\
\text { Rediers, Hans } \\
\text { Lievens, Bart }\end{array}$ \\
\hline Topics: & control, biological, control, chemical \\
\hline Organisms: & bacteria \\
\hline Other Keywords: & $\begin{array}{l}\text { Agrobacterium biovar 1, control, crazy roots, extensive root development, } \\
\text { hairy root disease }\end{array}$ \\
\hline & \\
\hline
\end{tabular}




\section{Rhizogenic agrobacteria in hydroponic crops: epidemics,}

$7{ }^{1}$ Laboratory for Process Microbial Ecology and Bioinspirational Management 8 (PME\&BIM), Department of Microbial and Molecular Systems, KU Leuven, Campus

9 De Nayer, B-2860 Sint-Katelijne-Waver, Belgium

$10 \quad{ }^{2}$ Research Centre Hoogstraten vzw, B-2328 Meerle, Belgium

$11{ }^{3}$ Research Station for Vegetable Production vzw, B-2860 Sint-Katelijne-Waver, Belgium

${ }^{4}$ Centre of Microbial and Plant Genetics, Department of Microbial and Molecular Systems, KU Leuven, B-3001 Leuven, Belgium

Running head: Rhizogenic agrobacteria

\$Shared last co-authorship.

21 "Correspondence: B. Lievens, Laboratory for Process Microbial Ecology and 22 Bioinspirational Management, KU Leuven, Campus De Nayer, Fortsesteenweg 30A, B232860 Sint-Katelijne-Waver, Belgium. Phone: +32 15 305590. Fax: +32 15 305599. E24 mail address: bart.lievens@kuleuven.be. 


\section{ABSTRACT}

26 Rhizogenic Agrobacterium biovar 1, harbouring a Ri-plasmid (root-inducing plasmid), 27 is the causative agent of hairy root disease (HRD) in the hydroponic cultivation of 28 tomato and cucumber. The disease is characterized by extensive root proliferation 29 leading to strong vegetative growth and, in severe cases, substantial losses in 30 marketable yield. Agrobacterium biovar 1 is a heterogeneous group of agrobacteria and 31 includes (at least) ten genomospecies, among which (at least) four genomospecies (G1, 32 G3, G8 and G9) have been associated with HRD in hydroponically grown vegetables. In 33 this review, we have synthesized the current knowledge on rhizogenic Agrobacterium 34 biovar 1, including infection process, current taxonomic status, genetic and phenotypic 35 diversity, detection methods and strategies for disease control. With regard to the latter, symptom reduction and prevention of infection through cultivation methods and

37 chemical disinfection (e.g. by the use of chlorine-based disinfectants and hydrogen peroxide) have been discussed. Additionally, we elaborate on biocontrol strategies. Recent research has lead to the identification of a phylogenetically related clade of Paenibacillus strains that have antagonistic activity against rhizogenic Agrobacterium

41 biovar 1 strains, holding great potential for HRD control. Finally, possible directions for 42 future research are proposed.

Key words: Agrobacterium biovar 1, control, crazy roots, extensive root development, hairy root disease. 


\section{SYMPTOMS AND GEOGRAPHIC OCCURRENCE}

Hydroponics involves growing plants in a mineral nutrient solution instead of soil and is an established method of producing vegetables such as tomato, cucumber, pepper and lettuce, as well as ornamental crops (e.g. herbs, roses and foliage plants). A major advantage of hydroponics, as compared with field grown crops, is that the crop is isolated from the soil, which often engenders problems of diseases, pests, salinity, poor structure and/or drainage (Litterick et al., 2004). Nevertheless, since the early 1990s hydroponically grown cucumber and melon plants, and later also eggplants and tomato crops, have been affected by a root disorder known as 'hairy root disease' (HRD; also known as 'hairy roots', 'crazy roots' or 'root mat'). HRD is characterized by extensive root proliferation within the rockwool cube and across the rockwool slab surface (Fig. 1), leading to strong vegetative growth with reduced fruit production. Additionally, affected roots are often prone to secondary infections, caused by e.g. Pythium and Pseudomonas species (Weller et al., 2006). Occasionally, plants showing HRD grow normally and yield is unaffected. Nevertheless, in most cases yield is severely reduced, e.g. up to more than $10 \%$ in tomato production (Bosmans L., unpublished results). Due to the persistent nature of HRD, an infested greenhouse is very likely to be re-infested in subsequent seasons, with increasing economic losses year by year. So far, the disease has been reported in several European countries, including Austria, Belgium, Denmark, France, Greece, the Netherlands, Poland, Switzerland, and United Kingdom (Ludeking et al., 2013). A survey performed in Flanders (Belgium) in 2014 indicated that $33 \%$ of the tomato, cucumber and eggplant producers were confronted with HRD (Moerkens et al., 2014). In the Netherlands, nearly half of the hydroponic growers has to deal with HRD (data of 2012; Ludeking et al., 2013). Since 2013, also cucumber and tomato crops in the Russian Federation have been affected by HRD where it has become one of 
73 the major problems in the greenhouse vegetable industry (Ignatov et al., 2016). In

74 addition, hairy roots has been reported in Japan, New Zealand and the USA (Sawada \& 75 Azegami, 2014).

\section{INFECTION PROCESS}

78 Although HRD is generally associated with pathogenic Rhizobium rhizogenes strains 79 (formerly Agrobacterium rhizogenes; Chandra, 2012; Escobar \& Dandekar, 2003; 80 Lindström \& Young, 2011), the disease on hydroponic crops is generally caused by Agrobacterium biovar 1 strains (Agrobacterium radiobacter) harbouring a rootinducing Ri plasmid (also referred to as 'rhizogenic agrobacteria') (Weller et al., 2000; 2004; 2006, Weller \& Stead, 2002). Strains that do not harbor an Ri plasmid are considered avirulent (Gelvin 2003; 2009). Symptoms arise following transfer and expression of a portion of the Ri plasmid, i.e. the so-called 'T-DNA' ('transferred DNA'), to the plant genome in a manner similar to that seen by tumour-inducing Ti plasmids in Agrobacterium tumefaciens (Hooykaas \& Beijersbergen 1994; Van Larebeke et al., 1974). The T-DNA on the Ri plasmid is defined by the so-called left and right border, comprised of $25 \mathrm{bp}$ direct repeats.

Ri plasmids can be classified according to the opines (i.e. a class of carbohydrate

91 derivatives that serve as a nutrient source for the agrobacteria) that are produced by 92 transformed cells (Wetzel et al., 2014). Mannopine- and cucumopine-type Ri plasmids contain a single T-DNA, whereas two T-DNA regions (TL-DNA (left T-DNA) and TR-

94 DNA (right T-DNA), separated from each other by non-transferred DNA) have been 95 identified in agropine-type Ri plasmids. The left T-DNA (TL-DNA) is about $20 \mathrm{~kb}$ in 96 length and encodes up to 18 potential genes, depending on the bacterial strain (Slightom 
et al., 1986; Nemoto et al., 2009). However, only 4 of the 18 loci have an essential role in the formation of hairy roots (White et al., 1985). These loci were named root locus genes A-D (rolA-D), which render plant cells more sensitive to endogenous auxins, leading to extensive proliferation of the roots (Nemoto et al., 2009; Shen et al., 1988). The right T-DNA (TR-DNA) contains genes involved in auxin and agropine biosynthesis (Chandra, 2011). The single T-DNA of mannopine- and cucumopine-type Ri plasmids shows homology to the TL-DNA and also contains the rol-locus responsible for induction of hairy root formation, but not the genes involved in auxin or opin biosynthesis (Brevet \& Tempe, 1988; Chandra, 2012).

Transfer of Agrobacterium T-DNA to the plant cell has been the subject of several reviews (e.g. Gelvin, 2009; Hwang et al., 2015; Lacroix \& Citovsky, 2016; Sheng \& Citovsky, 1996; Tzfira \& Citovsky, 2006). The gene transfer is mediated by the co-operative action of a number of virulence (Vir) proteins encoded by genes also present on the plasmid, collectively referred to as the virulence (vir) genes (Tzfira \& Citovsky, 2006; White \& Nester, 1980). The multi-step process of T-DNA transfer and insertion has been the focus of intense study, but some steps are still poorly understood. Briefly, following attraction to wounded host cells the bacteria loosely bind to the host cell surface, where they start synthesizing cellulose filaments that stabilize the binding, resulting in a tight association between Agrobacterium and the host cell. This process is facilitated by two chromosomal Agrobacterium genes, $\operatorname{chvA}$ and $\operatorname{chvB}$, that are involved in the synthesis of extracellular $\beta$-1,2-glucans, allowing Agrobacterium to attach to plant hosts (Giri \& Narasu, 2000). Subsequently, phenolic compounds secreted by the wounded plant cells (e.g. acetosyringone, lignin, flavonoid precursors) as well as sugar molecules and a low $\mathrm{pH}$ activate the VirA protein, the sensor of a 2-component regulatory system (Lacroix \& Citovsky, 2013). The activated VirA protein then acts as a 
122 kinase and phosphorylates the cytosolic response regulator VirG (Lee et al., 1995 Wise

123 \& Binns, 2015). Phosphorylated VirG acts as a transcriptional activator by binding to a

124 12-bp vir box located upstream of the transcription start sites of the vir genes 125 (Czarnecka-Verner et al., 2016). The VirD2 endonuclease in association with the VirD1 126 topoisomerase make a single-stranded cut at the T-DNA border sequence (Wang et al., 127 1987). Next, the 5 ' end of the T-DNA is covalently bound to VirD2 protein and is 128 removed by strand displacement (Chandra, 2012). In order to protect the excised single 129 stranded T-DNA from cytoplasmic nucleases of the host cell and to adapt it for nuclear 130 import, the T-DNA is coated with the single-stranded DNA binding protein VirE2 131 (Citovsky et al., 1989). Next, the T-DNA complex is directed to a type IV secretion system (T4SSs), which forms a transmembrane channel through which the T-DNA complex is transferred into the cytoplasm of the host plant cell (Chandran Darbari \& interaction with host proteins. Importin $\alpha$, which is part of the host nuclear import machinery, binds to the Nuclear Localization Signals (NLS) in VirD2 and facilitates import of VirD2 into the host nucleus. VirE2 proteins are bound indirectly to importin $\alpha$, through the VIP1 host protein (VirE2 Interacting Protein 1), which acts as an adaptor protein between VirE2 and importin $\alpha$ (Citovsky et al., 2004; Lacroix \& Citovsky, 2013; Tzfira et al., 2001; 2002). Once the T-DNA complex has arrived in the nucleus, the accompanying proteins are removed, presumably by the host ubiquitin-proteasome system, the complementary strand of the T-DNA is synthesized and the double stranded fragments are finally integrated into the plant host genome (Lacroix \& Citovsky, 2016). Subsequent expression of T-DNA genes results in synthesis and excretion of opines, 
147 which are utilized by Agrobacterium as a nutrient source (Dessaux et al., 1992).

148 Additionally, expression of the rolA-D genes render the plant cells more sensitive to 149 plant auxines leading to the typical HRD symptoms. Plant assays have shown that HRD 150 symptoms generally develop five to eight weeks after infection. Nevertheless, 151 sometimes three to four months are needed to develop symptoms.

\section{TAXONOMY}

154 Agrobacteria are Gram-negative, rod-shaped bacteria belonging to the class 155 Alphaproteobacteria and the family Rhizobiaceae, whose members represent a wide diversity of (plant) pathogens and non-pathogens including beneficial bacteria. The taxonomy of agrobacteria was historically based on disease symptoms: bacteria inducing crown galls were named Bacterium tumefaciens (Smith \& Townsend, 1907); root-inducing bacteria were named Phytomonas rhizogenes (Riker, 1930); and nonpathogenic agrobacteria were named Bacillus radiobacter. Based upon similarity in morphology and physiology among these bacteria, Conn (1942) proposed a new genus, Agrobacterium, comprising the species Agrobacterium tumefaciens (Smith \& Townsend, 1907), Agrobacterium rhizogenes (Riker et al., 1930) and Agrobacterium radiobacter. A. tumefaciens (type species) was the name given to Agrobacterium strains capable of inducing tumorigenic reactions in a wide range of host plant species. $A$. rhizogenes comprised strains capable of causing hairy roots in host plants, and $A$. radiobacter harboured non-pathogenic Agrobacterium strains (Conn, 1942). Afterwards, a number of additional species have been allocated to the genus, including Agrobacterium larrymoorei (infecting Ficus spp.), Agrobacterium rubi (infecting Rubus spp.) and Agrobacterium vitis (infecting Vitis spp.) (Bouzar et al., 1995). As pathogenicity traits of Agrobacterium depend on the type of plasmid hosted by the 
172 bacteria, it became clear that phytopathological properties were not valid for species 173 delineation (for a review, see van Berkum \& Eardly, 1998). Using a polyphasic 174 approach, various authors have recognized three large clusters in the genus 175 Agrobacterium (Table 1), corresponding to biovars 1, 2, and 3, as defined by Keane et 176 al. (1970). Biovars are determined by chromosomal genes and not plasmids, and 177 therefore better reflect phylogenetic relationships. As a result, tumorigenic, rhizogenic 178 and non-pathogenic strains can be found within the same biovar. More specifically, 179 biovar 1 contains strains of $A$. tumefaciens, A. rhizogenes and A. radiobacter, including the type strains of $A$. tumefaciens and A. radiobacter. Biovar 2 also contains strains of tumefaciens and A. vitis strains (Ophel \& Kerr, 1990; Panagopoulos et al., 1978).

In modern bacterial taxonomy, criteria to delineate taxa include genomic information in addition to, for example, morphological, physiological and biochemical features. Homogenous genomospecies is the ultimate criterion to validly delineate a bona fide species (Stackebrandt et al., 2002). Meeting this criterion, A. larrymoorei, $A$. rubi and A. vitis (biovar 3) have been validated as bona fide species (Bouzar \& Jones, 2001; Ophel \& Kerr, 1990). Agrobacterium biovar 1, however, is heterogeneous, including (at least) ten genomospecies currently called genomovar G1 to G9 (Mougel et al., 2002) and G13 (Portier et al., 2006), suggesting that biovar 1 comprises multiple species that have yet to receive a Latin binomial name. Remarkably, the type strains of the formerly described species "A. radiobacter" and "A. tumefaciens" were found to belong to the same genomospecies (G4). As a result, these species names are synonymous and should be renamed as "A. radiobacter" for antecedence reasons (Young et al., 2006). Costechareyre et al. (2010) proposed that the group of closely related taxa corresponding to biovar 1 should be collectively called the "A. tumefaciens 
197 species complex" in order to avoid confusion with genomic species G4 (which must be 198 validly named $A$. radiobacter) (Costechareyre et al., 2010). For the International 199 Committee on Systematics of Prokaryotes (ICSP) subcommittee on the taxonomy of 200 Rhizobium and Agrobacterium this seems to be a good interim solution until 201 genomospecies can be formally named (Lindström \& Young, 2011). Based on 16S ribosomal RNA (rRNA) gene phylogenies Young et al. (2006) proposed the genus Agrobacterium to be incorporated in the genus Rhizobium, but had not obtained a general agreement (Su et al., 2006). As a result, the ICSP subcommittee on the taxonomy of Rhizobium and Agrobacterium (Lindström \& Young, 2011) decided to only transfer $A$. rhizogenes, representing the most distantly related species, into the genus Rhizobium as Rhizobium rhizogenes. Consequently, $R$. rhizogenes is now a legitimate name for biovar 2 (Costechareyre et al., 2010). Interestingly, all strains currently known to induce hairy roots in hydroponic crops have been identified as Agrobacterium biovar 1 strains (Fig. 2) (Bosmans et al., 2015), whereas strains collected from infected plants in the soil belong to biovar 2. Nevertheless, Weller et al. (2004) have shown that Ri plasmids may be readily transferred to non-pathogenic agrobacteria or rhizobia, suggesting that novel pathogenic populations with novel characteristics may arise.

\section{GENETIC AND PHENOTYPIC DIVERSITY}

Whereas the genetic diversity of tumour-inducing agrobacteria has been studied extensively before (Llop et al., 2003; Pulawska \& Kaluzna, 2012), it is only since recently that the genetic and phenotypic diversity of rhizogenic Agrobacterium biovar 1 strains causing HRD on hydroponic crops has been assessed (Bosmans et al., 2015; Xiao et al., 2015). These studies showed that rhizogenic Agrobacterium biovar 1 strains 
222 have substantial genetic diversity, especially for chromosomal loci such as the trpE

223 gene (encoding the anthranilate synthase component I). For loci from the Ri plasmid,

224 such as rolB and virD2, genetic diversity was lower, indicating that the chromosomal

225 housekeeping genes and the Ri plasmid-borne loci have a different evolutionary history

226 (Bosmans et al., 2015). This is in agreement with the fact that Ri plasmids can be easily

227 transferred to other agrobacteria or rhizobia carrying no Ti or Ri plasmids (Weller et al.,

228 2004). Furthermore, it has been suggested that recombination events could have

229 contributed to the evolutionary dynamics of rhizogenic Agrobacterium biovar 1

230 populations (Bosmans et al., 2015). A genomospecies analysis based on phylogeny of

231 recA and rpoB sequences, encoding the DNA repair protein RecA and the $\beta$ subunit of

232 RNA polymerase, respectively, revealed that members of at least four genomospecies

233 may occur on hydroponically grown cucurbit and tomato crops, including

234 genomospecies G1, G3, G8 and G9 (Bosmans et al., 2015). While these studies have

235 undoubtedly contributed to a better understanding of the genetic structure within

236 rhizogenic agrobacteria, further research using more strains from diverse geographic

237 origins is needed to have a more comprehensive view on the population structure.

238 Rhizogenic Agrobacterium biovar 1 strains have also been shown to differ substantially

239 at the phenotypic level (Fig. 3). For example, although the majority of strains grow well

240 between 22 and $37^{\circ} \mathrm{C}$, some strains are also able to grow at $4{ }^{\circ} \mathrm{C}$ and/or at $44^{\circ} \mathrm{C}$.

241 Furthermore, the majority of strains grow well between $\mathrm{pH} 5$ and $\mathrm{pH} 9$ but some strains

242 are able to grow at more extreme values, i.e. as low as $\mathrm{pH} 3$ and as high as $\mathrm{pH} 11$.

243 Altogether, this shows that rhizogenic agrobacteria can thrive well under a broad range

244 of environmental conditions. Interestingly, most strains are able to form biofilms in

245 laboratory assays. Furthermore, strains have been identified that possess catalase 
246 activity, enabling them to resist hydrogen peroxide exposure which is a commonly used

247 disinfectant in hydroponic horticulture (Bosmans et al., 2015).

249 DETECTION AND QUANTIFICATION

250 Early detection, accurate identification and reliable quantification of pathogenic strains

251 are cornerstones for effective disease management. Detection and identification of

252 rhizogenic agrobacteria have been classically performed using plating on semi-selective

253 media (Brisbane \& Kerr, 1983; Schroth et al., 1965) followed by fatty acid profiling or

254 PCR detection of the Ri plasmid (Haas et al., 1995). Selective media to isolate

255 agrobacteria (Brisbane \& Kerr, 1983) are generally based on the particular ability of

256 agrobacteria to resist toxic compounds such as selenite $\left(\mathrm{Na}_{2} \mathrm{SeO}_{3}\right)$ or tellurite $\left(\mathrm{K}_{2} \mathrm{TeO}_{3}\right)$

257 salts. On tellurite-amended media, colonies exhibit a typical circular glistening

258 morphology with a characteristic black color and a metallic shine (Brisbane \& Kerr,

259 1983; Schroth et al., 1965). A major disadvantage of isolation-based detection and

260 identification, however, is time-consuming and the risk of getting false positives due to

261 lack of medium selectivity (Brisbane \& Kerr, 1983). Therefore, alternative methods

262 based on molecular approaches are increasingly developed and implemented for direct

263 detection and quantification of the bacteria. Weller \& Stead (2002) described the

264 development of a TaqMan-based quantitative real-time PCR (qPCR) assay to detect

265 Agrobacterium biovar 1 strains from diverse environmental samples after enrichment in

266 a selective medium. More recently, Bosmans et al. (2016a) developed a SYBR Green-

267 based qPCR assay based on the rol locus of the Ri plasmid for detection and

268 quantification of rhizogenic agrobacteria in hydroponic systems. The assay allowed the

269 authors to detect less than one bacterial cell per mL (Bosmans et al., 2016a), illustrating

270 its power for routine detection and quantification of rhizogenic Agrobacterium biovar 1 
271 strains. Importantly, the assay can be used for pathogen assessment before symptoms

272 develop or even before infection takes place, enabling to take preventative control 273 measures before plants become infected (Bosmans et al., 2016a).

\section{MANAGEMENT PRACTICES}

276 Once the T-DNA has been integrated into the plant genome, HRD cannot be controlled

277 by curative means. Instead, preventative actions should be taken before infection can 278 occur. Major strategies to prevent HRD include cultivation methods and chemical 279 desinfection by chlorine-based disinfectants or hydrogen peroxide $\left(\mathrm{H}_{2} \mathrm{O}_{2}\right)$. Besides, 280 biocontrol strategies using antagonistic strains are under investigation.

\section{Cultivation methods}

283 Excessive root proliferation favors vegetative growth over generative (reproductive) growth, decreasing fruit setting, fruit size and yield. To have sufficient and balanced fruit setting and yield, a good balance between vegetative and generative growth is necessary. During vegetative growth, a plant uses the products from photosynthesis to

287 grow more leaves and stems, while a generative plant is using these products to produce more fruit. However, fruit size and yield decrease if plants become either too generative or vegetative (Van Ieperen, 1996). Therefore, in order to reduce yield losses caused by rhizogenic agrobacteria, actions can be taken that benefit reproductive growth to correct for the excessive vegetative growth caused by the agrobacteria. This can be achieved by various cultivation methods, including choice of rootstock, crop variety (cultivar), growth substrate, irrigation strategy, etc. Most greenhouse tomatoes and cucurbits are grafted onto a rootstock, protecting the plants against diseases and abiotic stress. However, different rootstocks may have a different effect on plant growth favoring 
296 either vegetatitive or generative growth, and thus yield and fruit quality (Abdelmageed

$297 \&$ Gruda, 2009; Spornberger \& Pieber, 2007). Likewise, the crop variety is known to 298 have an impact on plant growth (Berg, 2009). Hydroponic crops are grown in a 299 substrate medium like rockwool, coco fibre, perlite or peat, each having its own 300 characteristics and requiring a specific irrigation strategy. Both the substrate medium 301 and irrigation strategy are known to have a great effect on whether a plant grows 302 primarily vegetative or generative (Aghdak et al., 2016), as well as on disease 303 development. For example, hydroponic eggplants grown on perlite have been shown to 304 develop less symptoms of HRD compared to rockwool (Wittemans, L., unpublished 305 results). Furthermore, irrigating at a lower frequency and using higher quantities of 306 feeding solution per irrigation cycle was found to decrease HRD symptoms more on a 307 rockwool substrate than on coco fibre. Increasing the irrigation frequency and using 308 lower quantities of nutrient solution on the other hand resulted in similar disease 309 severity at the end of the growing season (Floury, 2010). A common method applied in 310 French, Belgian and Dutch greenhouses that are infested with rhizogenic agrobacteria is 311 removing the upper part of the plastic cover of the growth substrate. Preliminary trials in practical conditions indicated that this method may reduce fruit yield lossess caused by HRD (Moerkens R., unpublished data). The underlying mechanisms of this observation, however, remain unclear so far, but it is reasonable to assume that light or control HRD, pruning of young leaves from the top of the plant may yield an adequate solution. Nevertheless, it is has to be noted that this is a time- and labor-consuming process. Alternative cultivation methods that may be able to reduce HRD may be found 
321 in the production of tree fruit. Here, excessive tree vigor can cause a lot of shoot growth

322 which leads to competition for nutrients and assimilates between shoots and fruits.

323 Treatments like root pruning and trunk incisions are used to finetune growth control,

324 flower bud development, fruit set and fruit quality (Maas, 2008). Additionally, the $\mathrm{pH}$

325 of the nutrient solution has been found to be an important factor in balancing vegetative

326 and reproductive growth in roses (Roosta \& Rezaei, 2014). However, the pH of the

327 nutrient solution can only vary within a limited range to prevent reduced availability of

328 nutrients for the plants.

330 Chemical disinfection

331 In most hydroponic systems the nutrient solution is recirculated and reused. The initial 332 water used can be sourced from diverse water supplies such as ponds, lakes, rivers and 333 reservoirs (Stewart-Wade, 2011). However, as these water sources can harbor plant 334 pathogens, they may present a possible source of pathogens entering the crop (Hong \& 335 Moorman, 2005). Moreover, when contaminated nutrient solution is recirculated, it 336 becomes a source of infection for the other plants in the irrigation system.

337 Currently, a variety of techniques are used to disinfect the nutrient solution 338 and/or irrigation pipes, including biocide application and exposure of the nutrient 339 solution to ultraviolet (UV) light (Pozos et al., 2004). Cationic surfactants such as 340 benzalkonium chloride $(\mathrm{BC})$, cetyltrimethylammonium bromide (CTAB), and Physan 34120 , a quaternary ammonium compound (a mixture of alkyl dimethyl benzyl ammonium 342 chloride and alkyl dimethyl ethyl benzyl ammonium chloride), have been shown to 343 eliminate $100 \%$ of tumorigenic agrobacteria in water suspensions treated at 7,5 , and 2 $344 \mathrm{ppm}$, respectively. Sodium hypochlorite eliminated $100 \%$ of the A. tumefaciens 345 population at $0.5 \mathrm{ppm}$ (Yakabe et al., 2012). As chlorine-based disinfectants may be 
346 degraded to potentially toxic, mutagenic and/or carcinogenic products posing potential

347 residue problems, in particular in the case of chlorate, the majority of growers have

348 shifted to apply $\mathrm{H}_{2} \mathrm{O}_{2}$ to control HRD, which is less hazardous for the environment.

349 However, as several rhizogenic Agrobacterium biovar 1 strains are catalase-positive and

350 able to tolerate $\mathrm{H}_{2} \mathrm{O}_{2}$ (Bosmans et al., 2015), $\mathrm{H}_{2} \mathrm{O}_{2}$ concentrations as high as $100 \mathrm{ppm}$

351 are needed to significantly reduce rhizogenic agrobacteria populations containing

352 catalase-positive strains. For catalase-negative strains, a treatment with 50 ppm $\mathrm{H}_{2} \mathrm{O}_{2}$

353 resulted in a significant reduction of the population in both biofilm and water (Bosmans

354 et al., 2016c). However, greenhouse experiments have shown that $\mathrm{H}_{2} \mathrm{O}_{2}$ concentrations

355 in the water circuit decrease with distance from the application point and are

356 consistently lower at the end of the irrigation circuit, most likely because it reacts with

357 organic material in the (biofilms of the) piping system (Bosmans et al., 2016c).

358 Interestingly, the lower hydrogen peroxide concentrations measured at the end of the

359 irrigation circuits correlate with a higher disease incidence at the end of the irrigation

360 circuit, illustrating the need for monitoring actual $\mathrm{H}_{2} \mathrm{O}_{2}$ concentrations in the water

361 circuit and/or $\mathrm{H}_{2} \mathrm{O}_{2}$ applications at additional sites throughout the irrigation system.

362

363 Biological control

364 There is an increasing demand from both government and consumers to reduce the use 365 of chemical pesticides and produce pesticide residu-free vegetables (Whipps \& 366 Lumsden, 2001). Indeed, as from January 2014 all EU professional growers are 367 obligated to apply Integrated Pest Management (IPM) (Directive 2009/128/EC), in 368 which biological, mechanical and chemical control methods are combined rationally 369 with a minimum use of chemical means (EUCIPM, 2014), reinforcing the need for 370 environmentally-friendly and sustainable alternatives. In this regard, much attention is 
371 given to biocontrol organisms (BCO) because of the ability of such antagonistic 372 organisms to suppress plant diseases with a narrow activity spectrum and less

373 environmental impact than chemical pesticides or disinfectants, and the possibility to be 374 integrated with other control methods (Raaijmakers et al., 2002). Especially rhizosphere 375 bacteria are generally considered ideal BCO of soilborne plant pathogens because of 376 their effective colonization of the rhizosphere providing a front-line defence against 377 pathogen attack, their versatility to protect plants under different conditions, and 378 production of antimicrobial compounds (Sharma et al., 2009). Research has shown that 379 A. tumefaciens can be successfully controlled with an avirulent $A$. rhizogenes strain 380 without Ri plasmid. This strain (K84) produces agrocin 84 which has a selective toxicity against $A$. tumefaciens (Penyalver et al., 2000). Studies indicate that K84 also illinoisensis, Paenibacillus pabuli, Paenibacillus taichungensis, Paenibacillus tundrae, produces agrocin 434 which would be active against $A$. rhizogenes (Penyalver et al., 2000). Nevertheless, agar overlay assays have shown that K84 is not able to inhibit the growth of rhizogenic Agrobacterium biovar 1 strains in vitro (Bosmans, L., unpublished results). Furthermore, it cannot be ruled out that this avirulent K84 strain may recieve the Ri plasmid from pathogenic strains via horizontal gene transfer (Weller \& Stead, 2002), and thereby become rhizogenic. For this reason, the use of strain K84 is currently not authorized in Europe.

Recently, a large collection of diverse bacterial strains has been screened for antagonistic activity against rhizogenic Agrobacterium biovar 1 strains using the agar overlay assay (Bosmans et al., 2016d). Interestingly, only Paenibacillus strains showed antagonistic activity and phylogenetic analysis showed that antagonistic activity was restricted to a particular Paenibacillus clade, representing the species Paenibacillus Paenibacillus tylopili, Paenibacillus xylanexedens and Paenibacillus xylanilyticus (Fig. 
396

397

398

399

400

401

402

403

404

405

406

407

408

409

410

411

\section{CONCLUSION AND PERSPECTIVES} action.

4). When a mixture of two strains identified as P. xylanexedens was evaluated for its biocontrol potential under greenhouse conditions, 17 weeks after artificial infection of tomato plants HRD incidence was found to drop with $30 \%$ compared to the control treatment where no antagonistic strains were applied, suggesting high biocontrol potential of the inoculum (Bosmans et al., 2016d). Although these results are highly promising, it can be assumed that biocontrol efficacy can even be enhanced by regular application of the BCO. However, it remains to be investigated whether these antagonistic strains also affect biofilm formation or are able to control agrobacteria that are residizing in biofilms. Preliminary characterization of the antagonistic compounds of both strains revealed that they are water-soluble and have low molecular weight. Furthermore, Bosmans et al. (2016d) suggested an important role of $\mathrm{Ca}^{2+}$ to produce and/or secrete these antimicrobial compounds, or to make rhizogenic agrobacteria vulnerable for these compounds (Bosmans et al., 2016b). Further research is needed to fully characterize these compounds, including their identity, production and mode of

Since its first appearing in hydroponic cucumbers in the UK at the beginning of the 1990s, HRD caused by rhizogenic Agrobacterium biovar 1 has rapidly spread in hydroponic cultivation of cucurbits, tomatoes and eggplants worldwide. Symptoms caused by rhizogenic agrobacteria can differ in terms of severity, ranging from no symptoms to heavily proliferated roots. So far, the host and bacterial factors as well as the abiotic factors that play a role in symptom development and severity of the disease remain unknown. Functional studies, e.g. through the use of transcriptomics and/or 
420 mutants, may help increasing our understanding of the host responses to Agrobacterium

421 infection. Future work could also be aimed at correlating the different genotypes and/or 422 phenotypes of Agrobacterium biovar 1 with differences in pathogenicity as well as 423 management strategies. Advantageously, these studies can benefit from recent whole 424 genome sequencing initiatives allowing in depth characterization of chromosomal and 425 plasmid DNA sequences (Slater et al., 2009). A preliminary analysis of the sequenced 426 genome of a rhizogenic Agrobacterium biovar 1 strain (NCPPB 2659 isolated from 427 Cucumis sativus) resulted in a genome assembly of 5,277,347 bp with a GC content of $42859.8 \%$ (Franco et al., 2016). Genome sequencing of representative biovar 1 isolates may 429 allow correlating genetic diversity with phenotypic differences in, for example, 430 virulence characteristics or biofilm formation capacity. Efforts for HRD control have 431 focused on several strategies to prevent HRD, including cultivation methods, chemical 432 disinfection and biological control. While these methods might work separately, a 433 combination of different methods would probably result in a better protection. Further 434 research could also be aimed at identifying resistance sources and the development and 435 implementation of resistant cultivars or rootstocks, e.g. in combination with suitable 436 BCOs, protecting the crops from infection with a minimum use of chemicals.

\section{Acknowledgements}

439 We thank VLAIO (Flanders Innovation and Entrepreneurship) to support this work 440 (project IWT-LA: 120761).

\section{Conflict of Interest}


443 No conflict of interest declared.

444 


\section{$445 \quad$ References}

446 Abdelmageed H, Gruda N, 2009. Influence of grafting on growth, development and 447 some physiological parameters of tomatoes under controlled heat stress conditions. 448 European Journal of Horticultural Science 74, 16-20.

449 Aghdak P, Mobli M, Khoshgoftarmanesh AH , 2016. Effects of different growing 450 media on vegetative and reproductive growth of bell pepper. Journal of Plant Nutrients $45139,967-973$.

452 Berg G, 2009. Plant-microbe interactions promoting plant growth and health: 453 perspectives for controlled use of microorganisms in agriculture. Appied Microbiology 454 \& Biotechnology 84, 11-18.

455 Ballas N, Citovsky V, 1997. Nuclear localization signal binding protein from 456 Arabidopsis mediates nuclear import of Agrobacterium VirD2 protein. Proceedings of 457 the National Academy of Sciences of the United States of America 94, 10723-10728.

458 Bosmans L, Álvarez-Pérez S, Moerkens R, Wittemans L, Van Calenberge B, Van 459 Kerckhove S, Paeleman A, De Mot R, Rediers H, Lievens B, 2015. Assessment of the 460 genetic and phenotypic diversity among rhizogenic Agrobacterium biovar 1 strains 461 infecting solanaceous and cucurbit crops. FEMS Microbiology Ecology 91, doi: $46210.1093 /$ femsec/fiv081.

463 Bosmans L, Paeleman A, Moerkens R, Wittemans L, Van Calenberge B, Van 464 Kerckhove S, De Mot R, Rediers H, Lievens B, 2016a. Development of a qPCR assay 465 for detection and quantification of rhizogenic Agrobacterium biovar 1 strains. European 466 Journal of Plant Pathology 145, 719-730. 
467 Bosmans L, De Bruijn I, De Mot R, Rediers H, Lievens B, 2016b. Agar composition 468 affects in vitro screening of biocontrol activity of antagonistic microorganisms. Journal 469 of Microbiological Methods 127, 7-9.

470 Bosmans L, Van Calenberge B, Paeleman A, Moerkens R, Wittemans L, Van 471 Kerckhove S, De Mot R, Lievens B, Rediers H, 2016c. Efficacy of hydrogen peroxide 472 treatment for control of hairy roots disease caused by rhizogenic agrobacteria. Journal 473 of Appied Microbiology, doi: 10.1111/jam.13187.

474 Bosmans L, De Bruijn I, Gerards S, Moerkens R, Van Looveren L, Wittemans L, Van 475 Calenberge B, Paeleman A, Van Kerckhove S, De Mot R, Rozenski J, Rediers H, 476 Raaijmakers J, Lievens B, 2016d. Potential for biocontrol of hairy root disease by a 477 Paenibacillus clade exhibiting antagonistic activity against rhizogenic Agrobacterium 478 biovar 1 strains. Frontiers in Microbiology. Submitted.

479 Bouzar H, Chilton WS, Nesme X, Dessaux Y, Vaudequin V, Petit A, Hodge NC, 1995. 480 A new Agrobacterium strain isolated from aerial tumors on Ficus benjamina L. Applied 481 Environmental Microbiology 61, 65-73.

482 Bouzar H, Jones, JB, 2001. Agrobacterium larrymooreisp. nov., a pathogen isolated 483 from aerial tumours of Ficus benjamina. International Journal of Sytematic and 484 Evolutionary Microbiology 51, 1023-1026.

485 Brevet J, Tempé J, 1988. Homology mapping of T-DNA regions on three 486 Agrobacterium rhizogenes Ri plasmids by electron microscope heteroduplex studies. 487 Plasmid, 19, 75-83. 
488 Brisbane PG, Kerr A, 1983. Selective media for three biovars of Agrobacterium. 489 Journal of Appied Bacteriology 54, 425-431.

490 Chandra S, 2012. Natural plant genetic engineer Agrobacterium rhizogenes: role of T491 DNA in plant secondary metabolism. Biotechnology Letters 34, 407-415.

492 Chandran Darbari V, Waksman G, 2015. Structural biology of bacterial type IV 493 secretion systems. Annual Review of Biochemistry 84, 603-629.

494 Citovsky V, Kapelnikov A, Oliel S, Zakai N, Rojas MR, Gilbertson, RL, Tzfira T, 495 Loyter A, 2004. Protein interactions involved in nuclear import of the Agrobacterium 496 VirE2 protein in vivo and in vitro. Journal of Biological Chemistry 279, 29528-29533.

497 Citovsky V, Wong ML, Zambryski P, 1989. Cooperative interaction of Agrobacterium 498 VirE2 protein with single-stranded DNA: implications for the T-DNA transfer process. 499 Proceedings of the National Academy of Sciences of the United States of America 86, $500 \quad 1193-1197$.

501 Colcombet J, Hirt H, 2008. Arabidopsis MAPKs: a complex signalling network 502 involved in multiple biological processes. Biochemistry Journal 413, 217-226.

503 Conn HJ, 1942. Validity of the genus Alcaligenes. Journal of Bacteriology 44, 353-360.

504 Costechareyre D, Rhouma A, Lavire C, Portier P, Chapulliot D, Bertolla F, Nesme X, 505 2010. Rapid and efficient identification of Agrobacterium species by recA allele 506 analysis. Microbial Ecology 60, 862-872. 
507 Czarnecka-Verner E, Salem TA, Gurley WB, 2016. Adaptation of the Agrobacterium 508 tumefaciens VirG response regulator to activate transcription in plants. Plant Molecular 509 Biology 90, 217-231.

510 Djamei A, Pitzschke A, Nakagami H, Rajh I, Hirt H, 2007. Trojan horse strategy in 511 Agrobacterium transformation: abusing MAPK defense signaling. Science 318, 453512456.

513 Dumas F, Duckely M, Pelczar P, Van Gelder P, Hohn B, 2001. An Agrobacterium 514 VirE2 channel for transferred-DNA transport into plant cells. Proceedings of the 515 National Academy of Sciences of the United States of America 98, 485-490.

516 Escobar MA, Dandekar AM, 2003. Agrobacterium tumefaciens as an agent of disease. 517 Trends in Plant Sciences 8, 380-386.

518 EUCIPM (2014) The European Centre for Integrated Pest Management. 519 (http://www.eucipm.org/).

520 Filippo M Di, Vila H, 2011. Influence of different rootstocks on the vegetative and 521 reproductive performance of Vitis vinifera L. Malbec under irrigated conditions. Journal 522 International des Sciences de la Vigne et du Vin 45, 75-84.

523 Franco JAV, Collier R, Wang Y, Huo N, Gu Y, Thilmony R, Thomson JG, 2016. Draft 524 genome sequence of Agrobacterium rhizogenes strain NCPPB2659. Genome 525 Announcements 4, e00746-16.

526 Gelvin SB, 1990. Crown gall disease and hairy root disease: A sledgehammer and a 527 tackhammer. Plant Physiology 92, 281-285. 
528 Gelvin SB, 2003. Agrobacterium-mediated plant transformation: the biology behind the 529 'gene-jockeying' tool. Microbiology and Molecular Biology Reviews 67,16-37.

530 Gelvin SB, 2009. Agrobacterium in the genomics age. Plant Physiology 150, 16655311676.

532 Giri A, Narasu ML, 2000. Transgenic hairy roots: recent trends and applications. 533 Biotechnology Advances 18, 1-22.

534 Gómez-López VM, Rajkovic A, Ragaert P, Smigic N, Devlieghere F, 2009. Chlorine 535 dioxide for minimally processed produce preservation: a review. Trends in Food 536 Science \& Technology 20, 17-26.

537 Haas JH, Moore LW, Ream W, Manulis S, 1995. Universal PCR primers for detection 538 of phytopathogenic Agrobacterium strains. Applied Environmental Microbiology 61, $539 \quad 2879-2884$.

540 Hong CX, Moorman GW, 2005. Plant pathogens in irrigation water: challenges and 541 opportunities. Critical Review of Plant Science 24, 189-208.

542 Hooykaas PJJ, Beijersbergen AG, 1994. The virulence system of Agrobacterium 543 tumefaciens. Annual Review of Phytopathology 32,157- 181.

544 Hwang HH, Gelvin SB, Lai EM, 2015. Editorial:“Agrobacterium biology and its 545 application to transgenic plant production”. Frontiers in Plant Science 6.

546 Ignatov AN, Khodykina MV, Vinogradova SV, Polityko VA, Pluschikov VG, Kornev 547 KP, 2016. First report of rhizogenic strains of Agrobacterium radiobacter biovar 1 
548 causing root mat of cucumber and tomato in Russia. Plant Disease doi.org: 549 10.1094/PDIS-11-15-1382-PDN.

550 Jakubowski SJ, Krishnamoorthy V, Cascales E, Christie PJ, 2004. Agrobacterium 551 tumefaciens VirB6 domains direct the ordered export of a DNA substrate through a type 552 IV secretion system. Journal of Molecular Biology 341, 961-77.

553 Keane PJ, Kerr A, New PB, 1970. Crown gall of stone fruits. II. Identification and 554 nomenclature of Agrobacterium isolates. Australian Journal of Biological Sciences 23, $555 \quad 585-595$.

556 Kim SE, Lee MY, Lee MH, Sim SY, Kim YS, 2014. Optimal management of tomato 557 leaf pruning in rockwool culture. Horticulture Environmental Biotechnology 55, 445558454.

559 Lacroix B, Citovsky V, 2013. The roles of bacterial and host plant factors in 560 Agrobacterium-mediated genetic transformation. International Journal of 561 Developmental Biology 57, 467-481.

562 Lacroix B, Citovsky V, 2016. A functional bacterium-to-plant DNA transfer machinery 563 of Rhizobium etli. PLoS Pathology 12, e1005502.

564 Lee YW, Jin S, Sim WS, Nester EW, 1995. Genetic evidence for direct sensing of 565 phenolic compounds by the VirA protein of Agrobacterium tumefaciens. Proceedings of 566 the National Academy of Sciences of the United States of America 92, 12245-12249.

567 Lindström K, Young JPW, 2011. International Committee on Systematics of 568 Prokaryotes. Subcommittee on the taxonomy of Agrobacterium and Rhizobium: 
569 Minutes of the meeting, 7 September 2010, Geneva, Switzerland. International Journal 570 of Systemic and Evolutionary Microbiology 61, 3089-3309.

571 Litterick AM, Harrier L, Wallace P, Watson CA, Wood M, 2004. The role of 572 uncomposted materials, composts, manures, and compost extracts in reducing pest and 573 disease incidence and severity in sustainable temperate agricultural and horticultural 574 crop production-A review. Critical Review of Plant Science 23, 453-479.

575 Llop P, Lastra B, Marsal H, Murillo J, López MM, 2003. Tracking Agrobacterium 576 strains by a RAPD system to identify single colonies from plant tumours. European 577 Journal of Plant Pathology 109, 381-389.

578 Ludeking D, Hamelink R, Wubben JP, Wubben J, Schenk MF, 2013. Aanpak van 579 overmatige wortelgroei in vruchtgroentegewassen. Wageningen UR Glastuinbouw $5801244,34$.

581 Maas F, 2008. Strategies to control tree vigour and optimise fruit production in 582 “Conference” pears. Acta Horticulturae 1, 139-146.

583 Moerkens R, Bosmans L, Wittemans L, Van Calenberge B, Van Kerckhove S, 584 Paeleman A, De Mot R, Rediers H, Lievens B, 2014. Gekke wortels vormen nieuwe 585 uitdaging. Managementand Techniek, 1.

586 Mougel C, Thioulouse J, Perrière G, Nesme X, 2002. A mathematical method for 587 determining genome divergence and species delineation using AFLP. International 588 Journal of Systematic and Evolutionary Microbiology 52, 573-586. 
589 Nemoto K, Hara M, Suzuki M, 2009. Function of the aux and rol genes of the Ri 590 plasmid in plant cell division in vitro. Plant Signals Behaviour 4, 1145-1147.

591 Ophel K, Kerr A, 1990. Agrobacterium vitis sp. nov. for strains of Agrobacterium 592 biovar 3 from grapevines. International Journal of Systematic Bacteriology 40, 236593241.

594 Panagopoulos CG, Psallidas PG, Alivizatos AS, 1978. Studies on biotype 3 of 595 Agrobacterium radiobacter var. tumefaciens. In Station de Pathologie Végétale et 596 Phytobactériologie, ed., Plant Pathogenic Bacteria Proc 4th Internat Conf Plant Path 597 Bact, Angers, France, 221-228.

598 Penyalver R, Vicedo B, López MM, 2000. Use of the genetic engineered 599 Agrobacterium strain K1026 for biological control of crown gall. European Journal of 600 Plant Pathology 106, 801-810.

601 Portier P, Fisher-Le Saux M, Mougel C, Lerondelle C, Chapulliot D, Thioulouse J, 602 Nesme X, 2006. Identification of genomic species in Agrobacterium biovar 1 by AFLP 603 genomic markers. Applied Environmental Microbiology 72, 7123-7131.

604 Pozos N, Scow K, Wuertz S, Darby J, 2004. UV disinfection in a model distribution 605 system: biofilm growth and microbial community. Water Research 38, 3083-3091.

606 Puławska J, Kałużna M, 2012. Phylogenetic relationship and genetic diversity of 607 Agrobacterium spp. isolated in Poland based on gyrB gene sequence analysis and 608 RAPD. European Journal of Plant pathology 133, 379-390. 
609 Raaijmakers JM, Vlami M, De Souza JT, 2002. Antibiotic production by bacterial 610 biocontrol agents. Antonie van Leeuwenhoek 81, 537-547.

611 Riker AJ, Banfield WM, Wright WH, 1930. Studies on infectious hairy root of nursery 612 trees of apples. Journal of Agricultural Research 41,507-540.

613 Roosta HR, Rezaei I, 2014. Effect of nutrient solution $\mathrm{pH}$ on the vegetative and 614 reproductive growth and physiological characteristics of rose cv. "Grand Gala" in 615 hydroponic system. Journal of Plant Nutrients 37, 2179-2194.

616 Sakalis PA, van Heusden GP, Hooykaas PJ, 2014. Visualization of VirE2 protein 617 translocation by the Agrobacterium type IV secretion system into host cells. 618 Microbiology Open. 3, 104-117.

619 Sawada H, Azegami K, 2014. First report of root mat (hairy root) of tomato 620 (Lycopersicon esculentum) caused by Rhizobium radiobacter harboring cucumopine $\mathrm{Ri}$ 621 plasmid in Japan. Japanese Journal of Phytopathology 80, 98-114.

622 Schroth MN, Thompson JP, Hildebrand DC, 1965. Isolation of Agrobacterium 623 tumefaciens, A. radiobacter group from the soil. Phytopathology 55, 645-647.

624 Sharma RR, Singh D, Singh R, 2009. Biological control of postharvest diseases of fruits 625 and vegetables by microbial antagonists: A review. Biological Control 50, 205-220.

626 Shen WH, Petit A, Guern J, Tempé J, 1988. Hairy roots are more sensitive to 413 auxin 627 than normal roots. Proceedings of the National Academy of Sciences of the United 628 States of America 85, 3417-3421. 
629 Sheng J, Citovsky V, 1996. Agrobacterium-plant cell DNA transport: have virulence 630 proteins, will travel. Plant Cell 8, 1699.

631 Slater SC, Goldman BS, Goodner B, Setubal JC, Farrand SK, Nester EW, Otten L, 632 2009. Genome sequences of three Agrobacterium biovars help elucidate the evolution 633 of multichromosome genomes in bacteria. Journal of Bacteriology 191, 2501-2511.

634 Slightom JL, Durand-Tardif M, Jouanin L, Tepfer D, 1986. Nucleotide sequence 635 analysis of TL-DNA of Agrobacterium rhizogenes agropine type plasmid. Identification 636 of open reading frames. Journal of Biological Chemistry 261, 108-121.

637 Smith EF, Townsend CO, 1907. A plant-tumor of bacterial origin. Science 25, 671-673.

638 Spornberger A, Pieber K, 2007. Influence of rootstocks on vegetative and reproductive 639 characteristics of "suncrest" and "redcal" peach in austria. Acta Horticulturae 732, 285640290.

641 Stackebrandt E, Frederiksen W, Garrity GM, Grimont PA, Kampfer P, Maiden MC, 642 Nesme X, Rossello-Mora R, Swings J, Truper HG, Vauterin L, Ward AC, Whitman 643 WB, 2002. Report of the ad hoc committee for the re-evaluation of the species 644 definition in bacteriology. International Journal of Systematic and Evolutionary 645 Microbiology 52, 1043-1047.

646 Stewart-Wade SM, 2011. Plant pathogens in recycled irrigation water in commercial 647 plant nurseries and greenhouses: their detection and management. Irrigation Science 29, $648 \quad 267-297$. 
$649 \mathrm{Su}$ S, Stephens BB, Alexandre G, Farrand SK, 2006. Lon protease of the $\alpha$ 650 proteobacterium Agrobacterium tumefaciens is required for normal growth, cellular 651 morphology and full virulence. Microbiology 152, 1197-1207.

652 Tempe J, Casse-Delbart F, 2012. Plant gene vectors and genetic transformation: 653 Agrobacterium Ri plasmids. Cell Culture and Somatic Cell Genetics of Plants 6, 25-49.

654 Tzfira T, Citovsky V, 2006. Agrobacterium-mediated genetic transformation of plants: 655 biology and biotechnology. Current Opinion in Biotechnology 17, 147-154.

656 Tzfira T, Vaidya M, Citovsky V, 2001. VIP1, an Arabidopsis protein that interacts with 657 Agrobacterium VirE2, is involved in VirE2 nuclear import and Agrobacterium 658 infectivity. EMBO Journal 20, 3596-3607.

659 Tzfira T, Vaidya M, Citovsky V, 2002. Increasing plant susceptibility to Agrobacterium 660 infection by overexpression of the Arabidopsis VIP1 gene. Proceedings of the National 661 Academy of Sciences of the United States of America 99, 10435-10440.

662 Van Berkum P, Eardly BD, 1998. Molecular evolutionary systematics of the 663 Rhizobiaceae. In The Rhizobiaceae. Springer Netherlands. 1-24.

664 Van Ieperen W, 1996. Effects of different day and night salinity levels on vegetative 665 growth, yield and quality of tomato. Journal of Horticultural Science 71, 99-111.

666 Van Larebeke N, Engler G, Holsters M, Van den Elsacker S, Zaenen I,Schilperoort, 667 RA, Schell J, 1974. Large plasmid in Agrobacterium tumefaciens essential for crown 668 gall-inducing ability. Nature 252, 169-170. 
669 Vankerckhoven E, Verbessem B, Crauwels S, Declerck P, Muylaert K, Willems KA, 670 Rediers H, 2011. Exploring the potential synergistic effects of chemical disinfectants 671 and UV on the inactivation of free-living bacteria and treatment of biofilms in a pilot672 scale system. Water Science Technology 64, 1247-1253.

673 Wang K, Stachel SE, Timmerman B, Van Montagu M, Zambryski PC, 1987. Site674 specific nick in the T-DNA border sequence as a result of Agrobacterium vir gene 675 expression. Science 235, 587-591.

676 Weller SA, Stead DE, Young JPW, 2004. Acquisition of an Agrobacterium Ri plasmid 677 and pathogenicity by other $\alpha$-Proteobacteria in cucumber and tomato crops affected by 678 root mat. Applied Environmental Microbiology 70, 2779-2785.

679 Weller SA, Stead DE, 2002. Detection of root mat associated Agrobacterium strains 680 from plant material and other sample types by post-enrichment TaqMan PCR. Journal 681 of Applied Microbiology 92,118-126.

682 Weller SA, Stead DE, O'neill TM, 2000. Root mat of tomato caused by rhizogenic 683 strains of Agrobacterium biovar 1 in the UK. Plant Pathology 49,799.

684 Weller SA, Stead DE, Young JPW, 2006 Recurrent outbreaks of root mat in cucumber 685 and tomato are associated with a monomorphic, cucumopine, Ri-plasmid harboured by 686 various Alphaproteobacteria. FEMS Microbiology Letters 258,136-143.

687 Wetzel ME, Kim KS, Miller M, Olsen GJ, Farrand SK, 2014. Quorum-dependent 688 mannopine-inducible conjugative transfer of an Agrobacterium opine-catabolic plasmid. 689 Journal of Bacteriology 196, 1031-1044. 
690 White FF, Nester EW, 1980. Hairy root: plasmid encodes virulence traits in 691 Agrobacterium rhizogenes. Journal of Bacteriology 141, 1134-1141.

692 Whipps JM, Lumsden RD, 2001. Commercial use of fungi as plant disease biological 693 control agents: status and prospects. In: Butt, T.M., Jackson, C.W. and Magan, N. (eds) 694 Fungal Biocontrol Agents: Progress, Problems and Potential. CAB International, 695 Wallingford, UK, 9-22.

696 White FF, Taylor BH, Huffman GA, Gordon MP, Nester EW, 1985. Molecular and 697 genetic analysis of the transferred DNA regions of the root-inducing plasmid of 698 Agrobacterium rhizogenes. Journal of Bacteriology 164, 33-44.

699 Wise AA, Binns AN, 2015. The Receiver of the Agrobacterium tumefaciens VirA 700 histidine kinase forms a stable interaction with VirG to activate virulence gene 701 expression. Frontiers in Microbiology 6, 1546.

702 Yakabe LE, Parker SR, Kluepfel DA, 2012. Cationic surfactants: Potential surface 703 disinfectants to manage Agrobacterium tumefaciens biovar 1 contamination of grafting 704 tools. Plant Disease 96, 409-415.

705 Young JM, Pennycook SR, Watson DRW, 2006. Proposal that Agrobacterium 706 radiobacter has priority over Agrobacterium tumefaciens. Request for an Opinion. 707 International Journal of Systematic and Evolutionary Microbiology 56, 491-493.

708 Xiao HU, Yao TA, Ting LI, Long JI, 2015. Study on tomato hairy root induction by 709 different Agrobacterium rhizogenes stains. Guangdong Agriculturale Science 3, 20-23. 
710 Zupan J, Hackworth CA, Aguilar J, Ward D, Zambryski P, 2007. VirB1* promotes T-

711 pilus formation in the vir type IV secretion system of Agrobacterium tumefaciens.

712 Journal of Bacteriology 189, 6551-6563. 


\section{FIGURES LEGENDS}

715

716 Figure 1. Hairy root disease on 4-month old hydroponically grown tomato plants. Left:

717 Healthy roots; right: extensive root proliferation caused by rhizogenic Agrobacterium 718 biovar 1.

719

720

721

722

723

724

725

Figure 2. Maximum likelihood consensus tree from concatenated sequences of four housekeeping genes (16S ribosomal RNA gene, recA,, rpoB and trpE) of all Agrobacterium biovar 1 and biovar 2 strains for which the sequences are present in Genbank (accessed October 2016). Node support values (bootstrap percentages, based on 1000 simulations) $\geq 90 \%$ are shown next to the branches. Bayesian inference posterior probabilities $\geq 90 \%$ and Neighbour-joining bootstrap node support values $\geq$ $90 \%$ are denoted by asterisks and daggers, respectively. The small phylogram is included to illustrate branch length heterogeneity (scale bar $=0.05$ nucleotide substitutions per site). Rhizobium tropici $\mathrm{LMG} 9503^{\mathrm{T}}$ was used as an outgroup to root the tree. All strains inducing hairy roots in hydroponic crops (indicated with a red dot) fall within the Agrobacterium biovar 1 clade (having LMG 187 as a representative strain), whereas strains causing hairy roots in soil-grown plants (indicated with a blue dot) group together within Agrobacterium biovar 2 (containing LMG $150^{\mathrm{T}}$ as a reference strain). Strains from unknown host/origin are not marked with a dot.

6

(1)


738 Figure 3. Beanplots illustrating the phenotypic diversity (growth temperature, $\mathrm{pH}$, 739 biofilm formation and resistance to hydrogen peroxide (300 ppm)) within a collection of 740 rhizogenic Agrobacterium biovar 1 isolates. Plots were made using all agrobacteria 741 studied by Bosmans et al. (2015). Each bean represents a one-dimensional scatter plot, 742 showing its distribution as a density shape. The solid line represents the average value 743 for each group; the dotted line represents the mean among the different groups.

744

745 Figure 4. Phylogenetic positioning of Paenibacillus strains showing antagonistic 746 activity against rhizogenic Agrobacterium biovar 1 strains. A maximum likelihood tree 747 was constructed based on $16 \mathrm{~S}$ ribosomal RNA gene sequences (1390 bp) for all type 748 strains of all Paenibacillus species currently described (163 species) and a number of 749 additional Paenibacillus strains tested (Bosmans et al., 2016d). Only a particular clade 750 of phylogenetically related paenibacilli was found to have antagonistic activity against 751 rhizogenic agrobacteria (indicated with an orange dot), while strains that were less 752 related to this clade did not (indicated with a blue dot). Strains without coloured dots 753 were not tested for antagonistic activity against Agrobacterium biovar 1. Major 754 bootstrap values $(\geq 85 \% ; 1000$ replicates) are shown at the nodes of the tree. 


\section{FIGURES}

Figure 1. Hairy root disease on 4-month old hydroponically grown tomato plants. Left: Healthy roots; right: extensive root proliferation caused by rhizogenic Agrobacterium biovar 1.
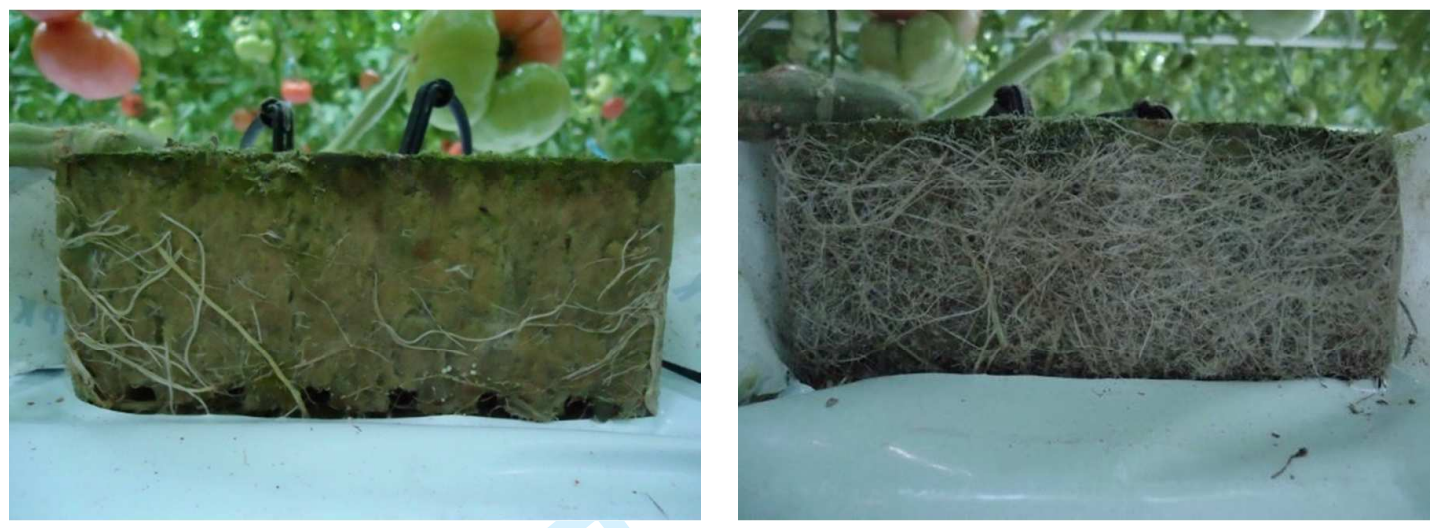

Figure 2. Maximum likelihood consensus tree from concatenated sequences of four housekeeping genes (16S ribosomal RNA gene, recA, rpoB and trpE) of all Agrobacterium biovar 1 and biovar 2 strains for which the sequences are present in Genbank (accessed October 2016). Node support values (bootstrap percentages, based on 1000 simulations) $\geq 90 \%$ are shown next to the branches. Bayesian inference posterior probabilities $\geq 90 \%$ and Neighbour-joining bootstrap node support values $\geq 90 \%$ are denoted by asterisks and daggers, respectively. The small phylogram is included to illustrate branch length heterogeneity (scale bar $=0.05$ nucleotide substitutions per site). Rhizobium tropici $\mathrm{LMG} 9503^{\mathrm{T}}$ was used as an outgroup to root the tree. All strains inducing hairy roots in hydroponic crops (indicated with a red dot) fall within the Agrobacterium biovar 1 clade (having LMG 187 as a representative strain), whereas strains causing hairy roots in soil-grown plants (indicated with a blue dot) group together within Agrobacterium biovar 2 (containing LMG $150^{\mathrm{T}}$ as a reference strain). Strains from unknown host/origin are not marked with a dot. 

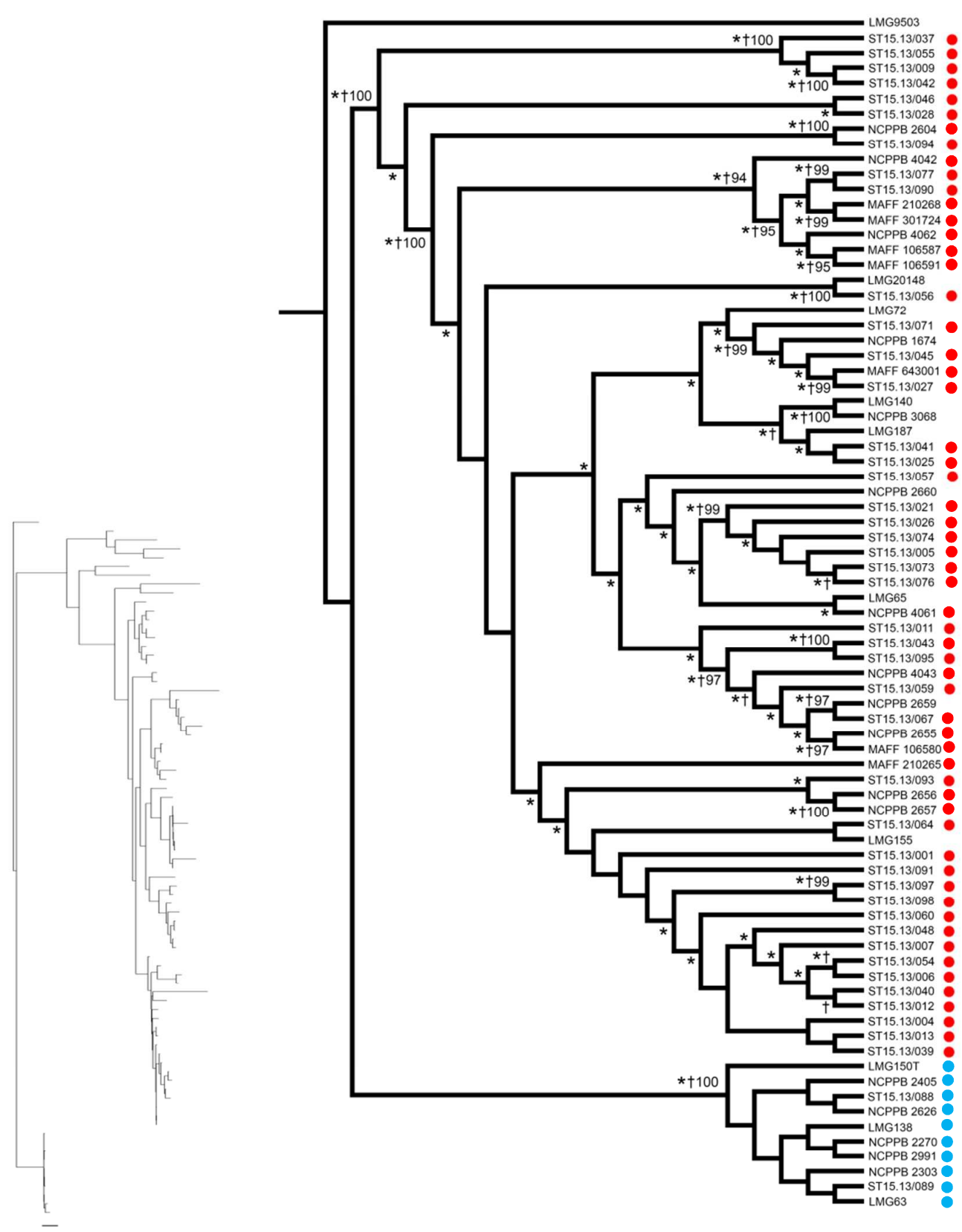

Biovar 1

Biovar 2 
Figure 3. Beanplots illustrating the phenotypic diversity (growth temperature, $\mathrm{pH}$, biofilm formation and resistance to hydrogen peroxide (300 ppm)) within a collection of rhizogenic Agrobacterium biovar 1 isolates. Plots were made using all agrobacteria studied by Bosmans et al. (2015). Each bean represents a one-dimensional scatter plot, showing its distribution as a density shape. The solid line represents the average value for each group; the dotted line represents the mean among the different groups.

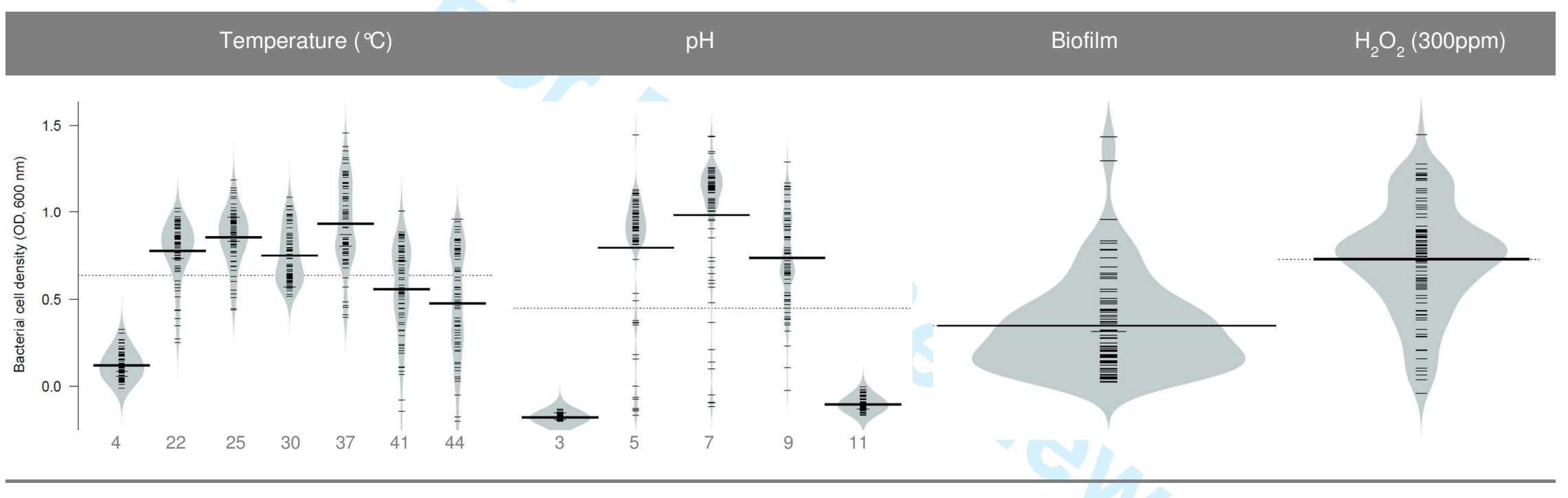


Figure 4. Phylogenetic positioning of Paenibacillus strains showing antagonistic activity against rhizogenic Agrobacterium biovar 1 strains. A maximum likelihood tree was constructed based on 16S ribosomal RNA gene sequences (1390 bp) for all type strains of all Paenibacillus species currently described (163 species) and a number of additional Paenibacillus strains tested (Bosmans et al., 2016d). Only a particular clade of phylogenetically related paenibacilli was found to have antagonistic activity against rhizogenic agrobacteria (indicated with an orange dot), while strains that were less related to this clade did not (indicated with a blue dot). Strains without coloured dots were not tested for antagonistic activity against Agrobacterium biovar 1 . Major bootstrap values $(\geq 85 \% ; 1000$ replicates) are shown at the nodes of the tree.

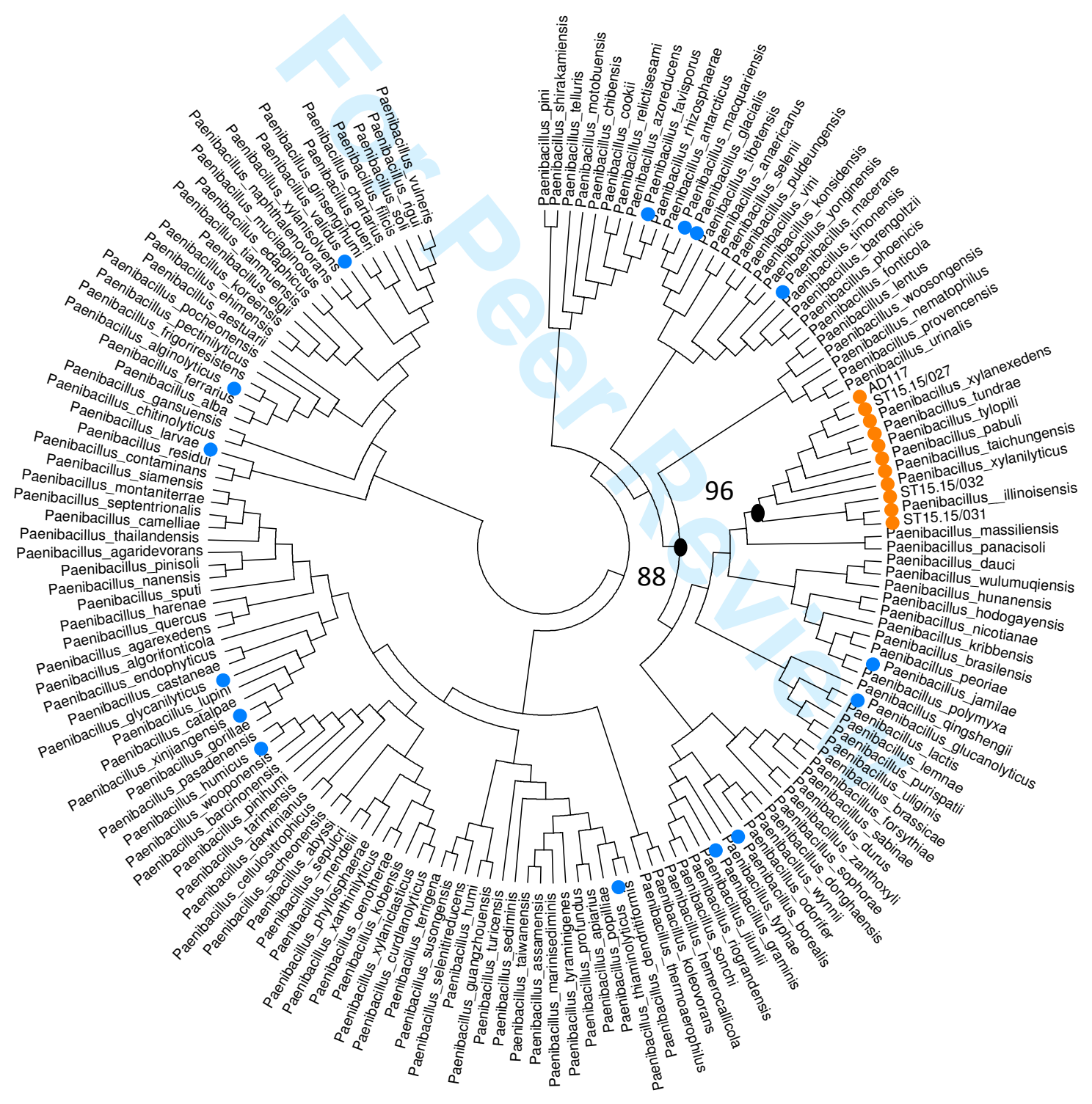




\section{TABLES}

Table 1. Classification of Agrobacterium strains.

\begin{tabular}{|c|c|c|}
\hline Old classification $^{a}$ & Biovar classification $^{b}$ & New classification $^{c}$ \\
\hline \multicolumn{3}{|l|}{ Agrobacterium tumefaciens } \\
\hline Agrobacterium radiobacter & $\begin{array}{l}\text { Biovar 1: tumorigenic }(A \text {. tumefaciens }) \text {, rhizogenic }(A \text {. } \\
\text { rhizogenes) and avirulent }(A \text {. radiobacter }) \text { strains, } \\
\text { includes type strains of } A \text {. tumefaciens and } A . \\
\text { radiobacter }\end{array}$ & $\begin{array}{l}\text { Agrobacterium tumefaciens species complex (LMG } \\
187^{\mathrm{T}} \text { ) }\end{array}$ \\
\hline Agrobacterium rhizogenes & $\begin{array}{l}\text { Biovar 2: tumorigenic (A. tumefaciens), rhizogenic A. } \\
\text { rhizogenes) and avirulent (A. radiobacter) strains, } \\
\text { includes type strain of } A \text {. rhizogenes }\end{array}$ & Rhizobium rhizogenes (LMG $150^{1}$ ) \\
\hline Agrobacterium rubi & - & Agrobacterium rubi (LMG 156 ${ }^{\mathrm{T}}$ ) \\
\hline Agrobacterium vitis & $\begin{array}{l}\text { Biovar 3: tumorigenic on Vitis (A. tumefaciens and A. } \\
\text { vitis) }\end{array}$ & Agrobacterium vitis (LMG $8750^{\mathrm{T}}$ ) \\
\hline Agrobacterium larrymoorei & - & Agrobacterium larrymoorei $\left(\mathrm{LMG} 21410^{\mathrm{T}}\right)$ \\
\hline
\end{tabular}

${ }^{a}$ As published in the International Journal of Systematic Bacteriology (International Journal of Systematic and Evolutionary Microbiology).

${ }^{\mathrm{b}}$ Based on a polyphasic classification approach.

${ }^{c}$ Based on Lindström and Young (2011). The type strain (LMG collection, Laboratory of Microbiology, Ghent University, Ghent, Belgium) is given between brackets. 